\title{
Monitoring of the phytosanitary efficiency of pre-sowing spring wheat seed treatment
}

\author{
Elena V. Pertseva*, Galina A. Burlaka, Lyudmila V. Kiselyova, Natalya V. Vasina, and Oksana P. Kozhevnikova \\ Samara State Agrarian University, Kinel 446442, Samara region, Russia
}

\begin{abstract}
For the forest-steppe of the Middle Volga region, efficiency of preparations for presowing treatment of seeds as regulators of the phytosanitary state of agrocenoses and spring wheat productivity for different regionalized varieties were assessed. To obtain stable phytosanitary agrocenoses, in the Middle Volga region, Kinel Yubileynaya variety should be cultivated with pre-sowing seed treatment using Epin Extra.
\end{abstract}

\section{Introduction}

A large zone for the production of high-quality wheat grain is the Middle Volga. New preparations used for the pre-sowing seed treatment can increase sowing properties and product yield. They make it possible to produce crops that meet modern requirements for grain quality. One of the modern pre-sowing seed treatment methods is application of fungicides and growth regulators that contribute to better plant growth and development [1].

The use of chemical plant protection products should be focused on the maximum use of selectively acting drugs and technologies, timeliness of measures, economic and environmental feasibility.

A correct choice of a drug for seed treatment which has a wide spectrum of action is crucial. Some protectants have a negative effect on the linear growth of seedlings. This reduces seed germination, plant density and productivity. Grain quality and crop productivity can be improved by using highly effective and environmentally friendly growth regulators [2-6].

In addition, resistant cultivars are used to combat pests and diseases. Therefore, before the mass introduction of a promising variety into production, phytosanitary monitoring should be carried out and the agrocenosis should be studied $[7,8]$.

The use of growth regulators and fungicides for presowing seed treatment does not mean an absolute success, but it helps reduce harmfulness of pests and produce safe grain products [9-12].

\section{Materials and methods}

\subsection{Research objects}

The objects of study are zoned varieties of spring wheat - Kinel Niva, Kinel Otrada, Kinel Yubileinaya, dressing agents - Maxim, Vitaros, plant growth regulators
- succinic acid, Epin Extra, Immunocytophytes, Zircon, NV 101 and a system of phytopathogens and phytophages forming in the agrocenoses.

The purpose is to increase the yield of spring wheat varieties by means of the pre-sowing seed treatment using dressing and growth regulators.

The research objectives are phytosanitary monitoring of crops of spring wheat varieties for various pre-sowing seed treatment options and a spring wheat yield analysis.

\subsection{Research methods}

Field studies were carried out on the experimental field in the first selective crop rotation of the spring wheat department of the Volga RI named after P.N. Konstantinov in 2014-16.

The field is located in the Central zone of Samara region or in the southern part of the Volga forest-steppe; the relief is even; afforestation of the surrounding territory is $8-10 \%$. Around the experimental field, there are old forest strips.

There were eight options of the two-factor experiment (for various preparations used for presowing seed treatment and three varieties of spring wheat). The area of the plot is $3 \mathrm{~m}^{2}$.

The location of the plots is systematic. Pre-sowing seed treatment was carried out manually according to the drug consumption rates presented in the Federal catalog of pesticides and agrochemicals approved for application in the Russian Federation. Laboratory research and field surveys were carried out by generally accepted methods.

\section{Results}

Pre-sowing seed treatment increased germination of spring wheat seeds in laboratory experiments. The best germination was observed in the variants using Maxim and succinic acid, Epin Extra and NV 101.

\footnotetext{
* Corresponding author: evperceva@mail.ru
} 
The best laboratory germination was observed after the pre-sowing seed treatment of Kinel Niva and Kinel Otrada. Laboratory germination was influenced by preparations, biochemical and physiological characteristics of the varieties, the level of infection with root rot pathogens, etc.

Field germination of spring wheat seeds changed in all the variants of pre-sowing seed treatment. Most often, the best field germination was observed after the pre-sowing treatment with Maxim or Vitaros and Epin Extra, Zircon or NV 101.

Moreover, Vitaros had a better effect than Maxim; in laboratory conditions, the best protectant was Maxim.

Zircon and NV101 had a positive effect on Kinel Niva and Kinel Otrada varieties. Kinel Yubileinaya seeds germinated better after being treated with Epin Extra, succinic acid and NV 101. Field germination results showed the best germination for Kinel Otrada and Kinel Yubileinaya. Field germination was higher after the presowing treatment with Epin Extra, NV 101, succinic acid and Zircon; the results coincide with the data of laboratory germination studies.

It should be noted that in 2014, the seeds were more infected with root rot pathogens than in 2015-2016 which is due to the use of seeds obtained from experimental plots (Fig. 1).

Protectants are more efficient in comparison with growth regulators. The difference between the level of grain infection is quite significant between the groups of preparations: $9.3 \%$ - for protectants and $42.4 \%$ - for growth regulators.

For the grain which is slightly infected with fungal colonies, the fungicidal effect of the presowing seed treatment with growth regulators and chemical dressing agents is pronounced. In 2015, the difference between the groups of preparations turned out to be 19.3 and $18.3 \%$; Epin Extra was the best for infected spring wheat seeds and root rot.

During the observation period, Maxim and Vitaros reduced the infestation of wheat seeds with fungal colonies. But it should be noted that Epin extra and Immunocytophyte also reduced the number of root rot pathogens. Chemical agents steadily reduced grain contamination and showed better efficacy only for heavily infected grain. Growth regulators effectively suppressed pathogenic microflora for Kinel Yubileinaya variety.

The infestation of Kinel Otrada and Kinel Yubileinaya seeds reduced when treated with Epin Extra. In both years of research, colonies of Bipolaris sorokiniana prevailed among root rot pathogens, and Fusarium and Penicillium colonies were found in seeds as well. To reduce the prevalence and degree of root rot, growth regulators exerted a greater effect than etchants, with the exception of NV 101 (Table 1).

60

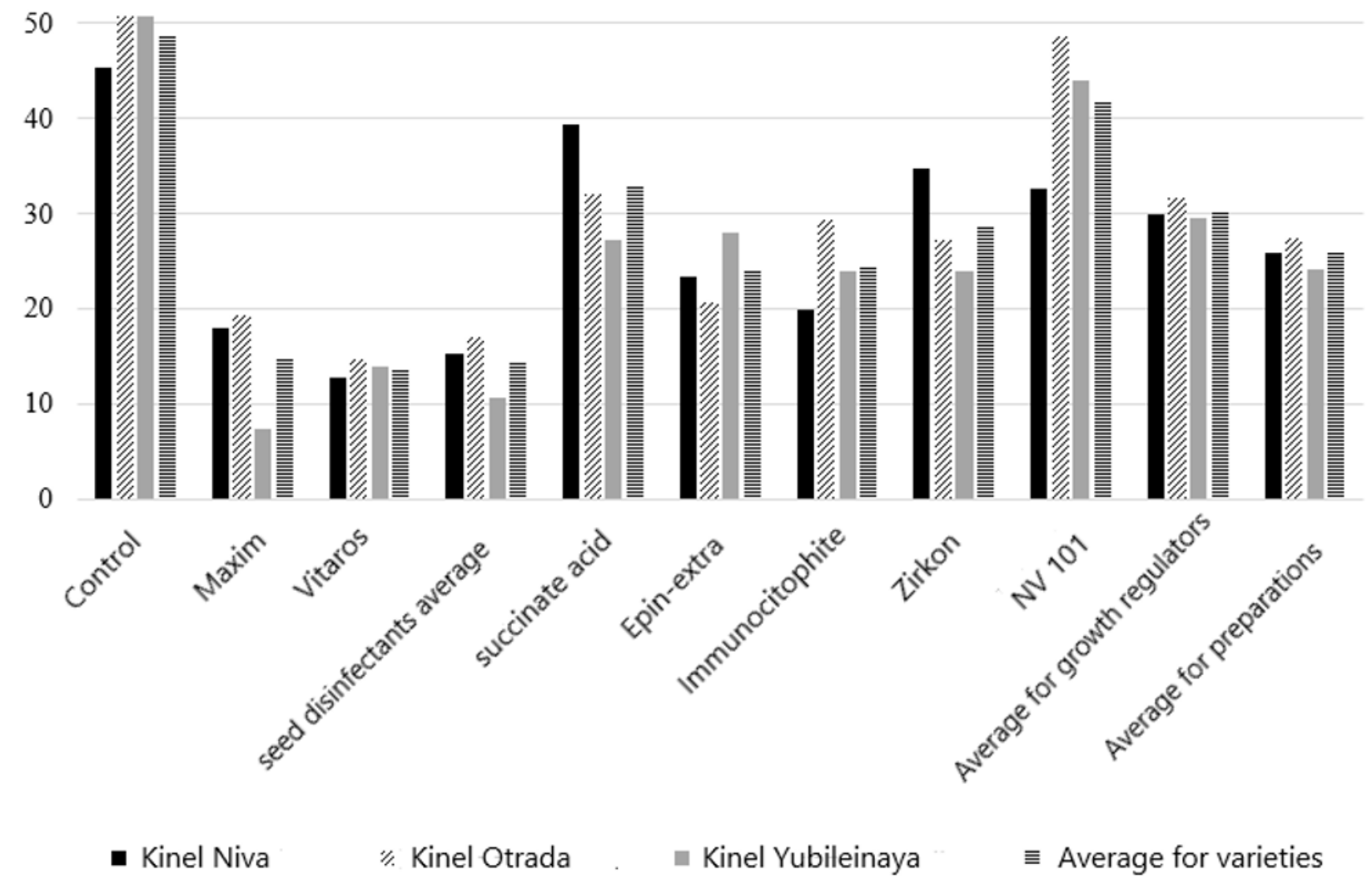

Fig. 1. Infection of spring wheat seeds with root rot depending on experimental options, $\%$ 
Table 1. Agrocenosis of spring wheat due to root rot depending on the experimental options, $\%$

\begin{tabular}{|c|c|c|c|c|c|c|c|c|}
\hline \multirow[b]{2}{*}{ Options } & \multicolumn{2}{|c|}{ Kinel Niva } & \multicolumn{2}{|c|}{ Kinel Otrada } & \multicolumn{2}{|c|}{ Kinel Yubileinaya } & \multicolumn{2}{|c|}{ Average } \\
\hline & \begin{tabular}{|c|} 
degree of \\
development
\end{tabular} & prevalence & $\begin{array}{c}\text { degree of } \\
\text { development }\end{array}$ & prevalence & $\begin{array}{c}\text { degree of } \\
\text { development }\end{array}$ & prevalence & $\begin{array}{c}\text { degree of } \\
\text { development }\end{array}$ & prevalence \\
\hline Control & 30.0 & 70.0 & 32.2 & 70.0 & 27.8 & 66.7 & 30.0 & 68.9 \\
\hline Maxim & 23.3 & 53.3 & 18.9 & 43.3 & 18.9 & 46.7 & 20.4 & 47.8 \\
\hline Vitaros & 18.9 & 46.7 & 27.8 & 56.7 & 20.0 & 46.7 & 22.2 & 50.0 \\
\hline $\begin{array}{c}\text { Average for } \\
\text { growth regulators }\end{array}$ & 21.1 & 50.0 & 23.4 & 50.0 & 19.5 & 46.7 & 21.3 & 48.9 \\
\hline Succinic acid & 17.8 & 43.3 & 16.7 & 36.7 & 13.3 & 33.3 & 15.9 & 37.8 \\
\hline Epin Extra & 23.3 & 53.3 & 22.2 & 43.3 & 20.0 & 46.7 & 21.8 & 47.8 \\
\hline Immunocytophyte & 22.2 & 50.0 & 17.8 & 40.0 & 18.9 & 43.3 & 19.6 & 44.4 \\
\hline \begin{tabular}{|l|} 
Zircon \\
\end{tabular} & 20.0 & 46.7 & 13.3 & 36.7 & 18.9 & 43.3 & 17.4 & 42.2 \\
\hline NV 101 & 26.7 & 56.7 & 23.3 & 53.3 & 23.3 & 56.7 & 24.4 & 55.6 \\
\hline $\begin{array}{c}\text { Average for } \\
\text { agents }\end{array}$ & 22.0 & 50.0 & 18.7 & 42.0 & 18.9 & 44.7 & 19.8 & 45.6 \\
\hline $\begin{array}{l}\text { Average for } \\
\text { preparations }\end{array}$ & 21.7 & 50.0 & 20.0 & 44.3 & 19.0 & 45.2 & 20.3 & 46.5 \\
\hline
\end{tabular}

It is due to the anti-stress effect of growth regulators on spring wheat plants in the field where other negative factors exerted on germinating seeds.

The effect of presowing seed treatment was more pronounced for Kinel Otrada and Kinel Yubileinaya varities; in Kinel Niva, root rot was less inhibited by the preparations.

In the field, the development of root rot was more effectively inhibited for Kinel Niva and Kinel Yubileinaya using succinic acid, and for Kinel Otrada using Zircon.

Pre-sowing treatment of spring wheat seeds reduced damage to seedlings by 2-3 times. In the agrocenosis, Kinel Niva was mot damaged after being treated with Immunocytophyte, Zircon and NV 101, Kinel Otrada with succinic acid and Maxim, Kinelskaya Yubileinoy with Maxim, succinic acid, Zircon and NV 101. This mismatch of damage is due to differences in the physiology and biochemistry of the varieties.

Treatment with NV 101 showed the best results. The less effective preparations were succinic acid, Epin Extra and Zircon.

Kinel Otrada was more significantly damaged by the striped flea due to its tender leaves; Kinel Niva and Kinel Yubileinaya were less damaged. This is especially pronounced in the crops of Kinel Yubileinaya, because in the control variant, this variety was the most damaged.

The bug-turtle chaotically damaged the spring wheat varieties, sometimes causing more harm to the options treated than the control one. Some positive effect was manifested in the options treated with Epin Extra, Immunocytophyte and NV 101. The least damaged variety was Kinel Niva.

More shrinkage of central leaves as a result of a damage caused by turtle bugs was observed in 2015 in untreated Kinel Yubileinaya seeds, Kinel Otrada seeds treated with Vitaros and Kinel Niva seeds treated with succinic acid.
The agrocenosis of Kinel Niva and Kinel Yubileinaya varieties was significantly thinned by the fly germ; Kinel Otrada crops were less damaged.

Growth regulators had a more significant effect on the resistance to a pest damage. The damage caused by the sprout fly after the pre-sowing treatment with NV 101 was reduced twice. Succinic acid, Epin Extra, and Zircon also reduced the sowing rate of the crops damaged by the sprout fly.

The pre-sowing treatment with NV 101 reduced a damage caused by phytophages. Plant extracts (Himalayan cedar, cypress, pine and plantain) supported and stimulated the immune system of spring wheat which affected the damage to seedlings in the initial period of its growth.

On average, over the years of research, the yield turned out to be higher after the pre-sowing treatment with succinic acid; at the same time, the yield rates for other pre-sowing seed treatment options did not differ much (Table 2).

$$
\text { NDS v. }=1.54 \mathrm{c} / \mathrm{ha} \text {, NDS A }=0.89 \mathrm{c} / \mathrm{ha} \text {, NDS B }
$$

$=0.54 \mathrm{c} / \mathrm{ha}(2014)$;

NDS v. $=0.34 \mathrm{c} / \mathrm{ha}, \mathrm{NDS} \mathrm{A}=0.20 \mathrm{c} / \mathrm{ha}$, NDS B

$=0.12 \mathrm{c} / \mathrm{ha}(2015)$;

NDS v. $=0.26 \mathrm{c} / \mathrm{ha}, \operatorname{NDS} \mathrm{A}=0.17 \mathrm{c} / \mathrm{ha}$, NDS B $=0.09 \mathrm{c} / \mathrm{ha}(2016)$.

The most productive agrocenoses of spring wheat were variants after the presowing treatment using growth regulators. Kinel Yubileinaya variety reacted more efficiently to the pre-sowing seed treatment by increasing the yield. The agrocenosis of Kinel Otrada was less responsive to the use of growth regulators and protectants.

Kinel Niva and Kinel Otrada varities were very productive after the pre-sowing treatment of grain infected with root rot pathogens using Immunocytophyte and slightly infected grain - using NV 101. Kinel Yubileinaya variety showed different immune response: succinic acid was used for heavily infected grain and Epin Extra - for less infected grain. 
Table 2. The yield of spring wheat depending on the experimental options, c/ha

\begin{tabular}{|c|c|c|c|c|}
\hline Options & Kinel Niva & Kinel Otrada & Kinel Yubileinaya & Average \\
\hline Control & 23.1 & 21.1 & 29.7 & 24.6 \\
\hline Maxim & 28.0 & 23.4 & 29.5 & 27.0 \\
\hline Vitaros & 25.8 & 22.2 & 30.7 & 26.2 \\
\hline Average for & 26.9 & 22.8 & 30.1 & 26.6 \\
\hline Succinic acid & 27.7 & 23.3 & 31.7 & 27.6 \\
\hline Epin Extra & 26.3 & 23.8 & 32.0 & 27.4 \\
\hline Immunocytophyte & 27.5 & 23.1 & 28.8 & 26.5 \\
\hline Zircon & 28.8 & 21.5 & 31.2 & 27.2 \\
\hline NV 101 BP & 27.2 & 23.7 & 31.2 & 27.3 \\
\hline Average for growth regulators & 27.5 & 23.1 & 31.0 & 27.2 \\
\hline Average for preparations & 27.3 & 23.0 & 30.7 & 27.0 \\
\hline
\end{tabular}

The lowest profitability was observed in Kinel Otrada treated with Epin Extra, and the highest - in Kinel Yubileinaya treated with Epin Extra.

In any case, it is important that despite the significant inhibition of phytopathogens by protectants, higher yields were observed after the presowing treatment of Kinel Yubileinaya variety with growth regulators.

\section{Discussion}

Agrocenoses of the varieties were damaged in different ways by a striped flea - Kinel Otrada variety was more damaged due to tender leaves; Kinel Niva and Kinel Yubileinaya were less damaged due to pre-sowing seed treatment. According to the average data, the best way to reduce damage was treatment using NV 101 seeds; succinic acid, Epin Extra and Zircon were less effective.

Turtle bugs randomly damaged the spring wheat agrocenoses, sometimes causing more harm when using preparations.

Kinel Niva and Kinel Yubileinaya varieties were damaged by larvae of the germ fly; Kinel Otrada variety was less damaged. The damage caused by the sprout fly when using NV 101 was reduced almost twice.

The infection rate for wheat seeds of Kinel Otrada and Kinel Yubileinaya varieties treated with Epin Extra decreased.

Root rot was reduced using succinic acid for Kinel Niva and Kinel Yubileinaya varieties, and using Zircon for Kinel Otrada variety.

Despite the best inhibition of phytopathogens by protectants, high yields were observed in variants with growth regulators for Kinel Yubileinaya variety.

\section{Conclusion}

The use of chemical plant protection products makes it possible to reduce the pesticidal load on beneficial inhabitants of the agrocenosis and produce safe grain products. The use of growth regulators and fungicides helps reduce harmfulness of some pests.

For a stable phytosanitary situation in the agrocenoses, it is recommended to cultivate Kinel Yubileinaya variety after the presowing seed treatment using Epin Extra.

\section{References}

1. E.V. Pertseva, G.A. Burlaka, Izvestia SSSA 4(1), 1418 (2016)

2. L. He, Z. Gao, R. Li, Afr. J. Biotechnol. 8, 6151-6157 (2009)

3. T. I. Balakhnina, P. Bulak, M. Nosalewicz, S. Pietruszewski, T. Wlodarczyk, Acta Physiologiae Plantarum 37(3), 37-59 (2015)

4. V.V. Borisenko et al., J. Pharm. Sci. \& Res. 10(10), 2626-2627 (2018)

5. G.A. Karpova, M.E. Mironova, Volga Niva 1, 8-13 (2009)

6. S.A. Kshnikatkin, P.G. Alenin, I.A. Voronova, Volga Niva 3(36), 71-77 (2015)

7. E.V. Pertseva, Entomological review 87(9) 1193-1200 (2007)

8. O.T. Kolye, N.I. Lozhkina, A.S. Prokuratova, N.A. Kalinenko, Fundamental research 8, 66-67 (2006)

9. B. Krzyzińska, M. Głazek, A. Mączyńska, ACTA AGROBOTANICA 58(1) 37-43 (2005)

10. R. Tahvonen, A. Hannukkala, H. Avikainen, Agricultural science in Finland 4, 419-427 (1995)

11. A.A. Razina, O.G. Dyatlova, Grain Farm of Russia 3(57), 67-71 (2018)

12. N.G. Vlasenko, S.S. Sleptsov, M.S. Samsonova, Siberian Bulletin of Agricultural Science 7-8, 5-10 (2011) 